\title{
Die diens van die Woord in die kerk
}

Dr. G. P. L van der Linde

\section{INLEIDING}

Die diens of bediening van die Woord in die kerk word gereel in artikels 3 - $10 \mathrm{KO}$.

Dit is opvallend hoe die uitdrukking diens of bedienaar van die Woord die artikels beheers. Dit beteken dat ons hier nie te doen het met iets wat deur iemand self besluit is of uit homself gesê word. Vir hom word gesê: Hier is die Woord, gaan maak dit bekend. So dien die bedienaar van die Woord (die een wat preek) die Een wat die Woord aan Hom gee. Maar die dinge hou nog meer in. Die bedienaar, die een wat preek, maak dit wat die Een wat die Woord aan hom gee aan dié bekend wat moet weet wat vir hulle gesê word. Hy bring ' $n$ boodskap. So dien of bedien die bedienaar van die Woord (die een wat preek) ook die vir wie die boodskap bedoel is, die Kerk.

Waar daar dan sprake is van diens of bediening van die Woord volg dit vanself dat daar geen willekeur in die diens mag wees nie. Elkeen kan nie maar die Woord gryp en daarmee maak wat hy wil nie. Die Een wie se Woord dit is, reel self die diens.

Die Ko reël nou die diens in die Gereformeerde Kerke. En dan vra ons

1. Wat die agtergrond vir die reëling is:

2. hoe die diens gereël is; en

3. of daar ook voorsiening vir die diens van die Woord moontlik is waar die KO in ' $n$ noodsituasie nie presies toegepas kan word nie.

\section{DIE AGTERGROND VIR DIE REËLING VAN DIE DIENS VAN DIE WOORD IN DIE KO}

In artikel 1 word in die KO self gesê waarom al die reëlings gemaak is - ook die van die diens van die Woord in artikels 3-9. Dit is nodig "om goeie orde in die kerk van Christus te onderhou . . ."

Twee uitdrukkings staan hier op die voorgrond. Eers die "goeie orde". Dit is 'n duidelike verwysing na 1 Kor 14 : 40 waar die Heilige Gees deur die apostel Paulus beveel: "Laat alles (in die kerk) welvoeglik en ordelik toegaan." Ons kan die bevel in die lig van die oorspronklike taal weergee as: Laat alles in die kerk gedoen word ooreenkomstig die voorskrifte of wette wat daarvoor gegee is. Die vraag is dan: Wie het die voorskrifte gegee? Die antwoord lê in die tweede uitdrukking van belang in art. 1: "die kerk van Christus."

En die uitdrukking vind weer 'n verklaring in o.a. art. XXVII NGB. Die kerk is "'n heilige vergadering" van almal wat in Christus glo, wat hulle hele saligheid in Jesus Christus verwag en gewas is deur die bloed, geheilig en verseèl deur die Heilige Gees.'

Die kerk is dus volgens ons belydenis: mense wat bymekaar gemaak is.

^Voordrag gehou te Sibasa. Venda, op 10-11 Oktober 1986 voor sendelinge. predikante. ouderlinge, helpers en evangeliste van die Christelijke Gereformeerde Kerken in Nederland en die Gereformeerde Kerke in Soutpansberg 


\section{In die Skriflig}

Wie het hulle bymekaar gemaak? Ons tweede belydenisskrif, die Heidelbergse Kategismus sê "dat die Seun van God uit die ganse menslike geslag vir Hom 'n gemeente (kerk) wat tot die ewige lewe uitverkies is deur sy Gees en Woord . . vergader" (S.XXI).

1. Die kerk is dan 'n vergadering, mense wat bymekaar gemaak is.

2. Die mense is tot die ewige lewe uitverkies.

3. Die mense word bymekaar gemaak deur die Seun van God - Jesus Christus;

4. Hy doen dit deur sy Woord en Gees;

5. Hy doen dit "van die begin van die wêreld af tot die einde toe" (art. XXVII), om hulle

6. te beskerm en te onderhou (S.XXI); te versorg.

Artikel I van die KO laat op grond van die belydenis geen twyfel nie dat as mens van die kerk praat, dan praat jy van die eiendom van God wat Hy vir Homself verkry het deur Jesus Christus. Die belydenis is hier die weergawe van die hele openbaring van God.

Ons sien sy kerk weliswaar nog in 'n vae omlyning vanaf die sondeval in die Paradys toe Hy eers gepraat het van die saad van die vrou wat die saad van die slang se kop sal vermorsel. Daarmee sê Hy hoe $\mathrm{Hy}$ die Satan sal oorweldig en hoe Hy die mense weer na Hom toe sal terugbring.

Deur die voortgaande openbaring sê Hy met nadruk eers deur die sondvloed dat nie al die mense weer na Hom sal kom as Hy roep nie. Net Noag en sy huisgesin oorleef die oordeel en hulle bly net lewe omdat die Here hulle lewe beskerm in die ark. Hy sorg dat uit die mensheid wat na Hom nie wil luister nie en daarom veroordeel is, Noag en sy gesin gered word. Hulle behoort aan Hom. Hy roep hulle na Hom toe.

Daarna, as die nakomelinge van Noag weer so ontaard het dat hulle hul $\mathrm{krag}$ in die toringbou van Babel wil toon, jaag Hy hulle uitmekaar en roep onder hulle een man Abram met sy vrou uit en sê dat Hy hom 'n groot nasie sal maak en hom tot 'n seen sal stel. Abram het geen kinders nie en hy en sy vrou is so oud dat hulle nooit kinders kan hê nie - en tog sê die Here aan Abram dat Hy sy verbond met hom en sy nageslag oprig. Dan nie met 'n nageslag uit Israel nie (Gen 18) maar wel met 'n seun wat uit Sara gebore sou word.

So laat die Here verstaan dat die volk met wie Hy sy verbond maak, wat Hy na Hom toe roep om saam met Hom te leef, ' $n$ wondervolk is. Die wondergeboorte van Isak wys hoe die Here deur 'n wonder vir Hom 'n volk gebore laat word in die wêreld. Hy sê dan ook deur die Psalmdigter: "Erken dat die HERE God is: Hy het ons gemaak, en ons is syne, sy volk en die skape van sy weide" (Ps 100).

Deur die manier waarop die HERE met sy volk Israel omgaan, leer Hy voortgaande dat Hy dit vir sy volk alleen deur die bloed van versoening moontlik maak om na Hom te kom en by Hom te bly. Eers in Egipte toe hulle getrek het, het die doodsengel by sy volk, wat aangewys is deur die bloed van die Paaslam, verby getrek. Net dié wat deur die bloed gedek is, was sy volk.

By Sinai is die offerdiens gereel wat nadruk daarop gelê het dat hulle alleen sy volk is omdat Hy hulle sondes vergeef deur die vergieting van offerbloed en die reiniging wat daarop volg.

Uiteindelik is die Christus, die saad van die vrou, gebore en Hy is deur 
die Here self aangewys as die Paaslam wat geslag is om die sondes van sy volk weg te neem. En hierdie volk, sê die Heilige Gees, is nou uit alle volke - die ander volke is soos takke van 'n wilde boom op 'n mak boom ingeënt. Die boom is Abraham en die Heilige Gees het deur die geloof in Christus die wat aan Hom behoort uit ander volke op Abraham as stam ingelyf, om so die volk van die Here, die Kerk, vandag te vorm. Die Kerk is die wat Hy in Christus uitverkies het voor die grondlegging van die wêreld (Ef 1:4) en die wat Hy tevore geken het, die het Hy ook geroep (Rom $8: 30$ ) en hulle het Hy ook deur sy Gees die geloof as gawe gegee (Ef $2: 8$ ).

En so sê die Belydenis en daarom die KO: onthou as julle praat van die kerk en met die kerk te doen het. Die Here self sê dit is 'n wonder dat daar 'n kerk is. Hy het die wonder laat gebeur en Hy alleen het seggenskap oor hierdie wonder wat voor ons oe opgerys het. Ons, die kerk, is die skape van sy weiding. Hy is ons Herder (Ps 23). Die Goeie Herder, Jesus Christus, laat sy skape wei (Joh 10). Daarom is daar voorskrifte of wette wat Christus gegee het sodat daar goeie orde in sy kerk kan wees, ook met die oog op die diens van die Woord.

\section{DIE REËLINGS VAN DIE DIENS}

Jesus Christus is die Goeie Herder. Hy "beskerm en onderhou" sy Kerk. Hy sê wat daarin nodig is om die "goeie orde", wat Hy voorskryf, te onderhou, ook wat die diens van die Woord betref.

Hoe moet ons dit nou verstaan? As Jesus Christus self die diens reel, is dit dan reg dat ons gebind word deur 'n Kerkorde, wat deur ' $n$ sinode saamgestel is?

Die antwoord op die vrae lê ook in artikel 1 "Om goeie orde in die kerk van Christus te onderhou is daarin nodig die dienste..." Met die woordjie "nodig" bepaal die artikel dan in die lig van wat ons van Christus as Here van die kerk gesê het, dat daar dienste moet wees omdat Hy dit so wil hê. Dit vind ons reeds by Israel. Die Here lei self sy volk uit Egipte as 'n georganiseerde gemeenskap (cf. Eks en Num). Maar Hy doen dit deur Moses. Hy sê aan Moses wat hy moet doen. En as die Here by Sinai die erediens, die besondere ontmoeting van God en sy volk, reèl deur Moses, is die stam van Levi afgesonder om wat nodig is met betrekking tot die besondere ontmoeting, te doen. Daarna is Aäron en sy seuns uit die stam aangewys om die priesteramp te bedien - om die Woord van die Here aan die volk deur te gee en om die offers te bring. Hulle was in die OT die bedienaars van die Woord wat die Here self aangestel het en hulle is blykens o.a. Levitikus 8 openlik in die diens aangestel deur 'n besondere seremonie. Die priesters is gewas en die priesterklere met die toebehore aangetrek en hulle werk is tot in die fynste besondernede deur die Here aan hulle voorgeskryf.

Net hulle kon die werk doen. Korag, Datan en Abiram het teen Moses en Aäron saamgekom en vir hulle gesê: "Dit is nou genoeg. Die hele gemeente, elke lid daarvan, is gewy en die Here is by hulle. Waarom verhef julle jul dan bo die gemeente van die Here?" Hulle sé dus dat elke lid van die kerk geregtig is om die Woord te bedien.

Moses het die saak voor die Here gebring, en Hy het gewys dat alleen die wat Hy vir die diens aangewys het, dit mag verrig. Die manne wat hulle in die diens ingedring het, is met 'n rreeslike oordeel getref. 


\section{In die Skriflig}

Die Here het die aarde laat oopskeur en hulle is daarin opgesluk en lewend begrawe.

So is dit reeds uit die Ou Testamentiese Kerk duidelik dat

1. die Here self die wat Hy vergader organiseer.

2. Die Here self sê dat mense dit moet doen in sy Naam;

3 . hulle moet aan sy volk sê wat Hy sê;

4. Hy laat sy Woord bedien deur mense wat Hy daarvoor aanwys daartoe roep en

5. dat niemand anders die diens mag verrig nie. Wie dit dan tog doen sonder dat die Here hom aangestel het, kom onder sy oordeel.

Later tree die profete ook as bedienaars van die Woord onder Israel op. En dan is dit opvallend hoedat daar elke keer noukeurig aangetoon word dat die Here die profeet roep en bekwaam maak vir sy werk. Dink maar hoe die Here in sy oorweldigende heerlikheid aan Jesaja verskyn en hom gestuur het as boodskapper (Jes 6) nadat hy eers daarteen opgesien, maar die Here hom bekwaam gemaak het ( $6: 5$ en 6 ).

Dieselfde gebeur met Jeremia. Elke profeet in die Ou Testament beklemtoon eers sy roeping en dat die boodskap wat hulle bring, nie hulle eie opinies is nie. Hulle toon telkens dat hulle net dienaars van die Here, bedienaars van sy Woord, is. Daarom klink telkens uit hulle mond: "So sê die Here HERE . . ."

Telkens sien ons ook hoedat valse profete wat om loon mense na die mond gepraat het, hulle opdring teenoor die ware profeet tot hulle eie oordeel - soos in die geval van die 400 valse profete wat Agab gevlei het teenoor Miga, die profeet van die Here!

Ook by die profete staan dus voorop die

1. roeping;

2. die opdrag om net die Here se Woord te spreek en

3 . die oordeel oor die indringers, die valse profete.

Dieselfde beginsel beheers die diens van die Woord in die Nuwe Testament. Jesus roep, en maak die apostels self bekwaam, leer hulle om vissers van mense te wees. Na sy opstanding beveel Hy hulle: "Gaan dan heen, maak dissipels van al die nasies, en doop hulle in die Naam van die Vader en die Seun en die Heilige Gees, en leer hulle om alles te onderhou wat Ek julle beveel het" (Matt $28: 19$ ). Om die plek van Judas te vul moes die gelowiges, onder leiding van Petrus, 'n apostel kies. Hulle stel twee name voor en een is deur die lot aangewys.

Hier tree 'n nuwe beginsel na vore. Die Here roep nog self tot die diens, maar gebruik die reeds bymekaar gemaakte gelowiges om die roeping in sy Naam te laat uitgaan.

Die apostels doen dan wat aan hulle gesê is en deur hulle bediening van die Woord maak Jesus deur die werking van die Heilige Gees nou die wat die Vader aan Hom gegee het, bymekaar. Voortaan sou die roeping tot die diens van die Woord steeds uitgaan van die kerk self, maar dan in die Naam van Jesus (cf. Hand).

Aan die begin is die diens van die Woord in alle dele, nl die prediking, regering en barmhartigheidsoefening, deur die apostels waargeneem. Gou het die omvang van die opdrag te veei geword en stel die apostels die regeer- (ouderling-) en diakenamp in en behartig self die preekwerk, die diens van die Woord in besonder. Dit het ingehou die preek, die aan- 
kondiging en onderrig van wat die Here sê en dit kom neer op die lees, uitleg en toepassing van die Woord

1. aan heidene om die wat die Vader aan die Seun gegee het bymekaar te maak en hulle dan

2. te leer om alles te onderhou wat Jesus hulle beveel het.

Verder moes hulle ook die bediening van die sakramente behartig.

Die apostels het hierdie besondere diens van die Woord oorgedra "aan manne wat bekwaam sal wees om ander te leer." Manne wat gearbei het in die Woord en leer. Ons noem hulle bedienaars van die Woord of predikante. Dit sluit aan by die Ou Testament want

1. Jesus gee aan hulle die opdrag om die Woord te bedien, om te preek.

2. Hy roep hulle self om dit te doen, maar Hy gebruik die gemeente om hulle in sy Naam te roep.

3. Die gemeente kan nie sommer enigeen roep nie; net die wat bekwaam is om ander te leer en wat aan die vereistes voldoen wat die Heilige Gees deur die apostels voorskryf in 1 Tim 3.

Die apostel Paulus vat die beginsels saam in Rom $10: 13$ vv as hy sê:

"Want elkeen wat die Naam van die Here aanroep, sal gered word. Hoe kan hulle Hom dan aanroep in wie hulle nie geglo het nie? En hoe kan hulle hoor sonder een wat preek? En hoe kan hulle preek as hulle nie gestuur word nie?" Die apostel Petrus waarsku 0.a. ook teen valse leraars, die wat hulleself in die diens indring.

Sowel die Ou as die Nuwe Testament toon dus onbetwisbaar dat in die Kerk van Christus, omdat Hy dit wil,

1. daar dienste moet wees:

2. die wat die diens waarneem moet geroep wees;

3 . Hy het eers die dienaars self direk geroep, maar doen dit in die laaste tye deur sy kerk.

4. Die kerk moet eers, deur die gawe te beproef, vasstel wie geroep mag word en

5. Valse dienaars wat hulle self indring in die diens moet geweer word en deur die kerk nie ontvang word nie. Paulus en Jesus self in Openbaring praat van die wat hulleself apostels noem maar dit nie is nie (Op $2: 2$ ). Die NGB vat die beginsels saam in Art. XXX en XXXI terwyl die Kerkorde die reëling of bepaling van Christus weergee, veral in art. 3.

Die roeping beheers die diens van die Woord, sonder roeping is, daar geen diens nie. "En niemand neem die waardigheid vir homself nie, maar hy wat deur God geroep word" (Heb $5: 4$ ).

Die bepalings van die KO waardeur die diens van die Woord gereel word, is ten slotte dan nie 'n magsvergryp waardeur die vrye lewe van die Gees in die kerk van Christus beklem word, soos M. R. van der Berg in Gekerkerde Kerk sê nie. Dit is juis die bepalinge van die Opperherder self waardeur Hy sy Woord deur die werking van sy Gees laat dien tot vergadering, versorging en bewaring van sy skape, sy Kerk.

"En Hy het gegee sommige as apostels . . . om die heiliges toe te rus vir dienswerk tot opbouing van die liggaam van Christus" (Ef 4:11 en 12). 
III. MOONTLIKHEID OM VOORSIENING VAN DIE DIENS VAN DIE WOORD WAAR DIE KO IN 'N NOODSITUASIE NIE PRESIES TOEGEPAS KAN WORD NIE.

Daar moet, volgens die Skrif en Belydenis, in elke kerk 'n bedienaar van die Woord wees wat getuienis het van sy beroeping en daarom seker is dat dit van die Here kom (NGB XXXI). Getrou aan die belydenis is die wettige beroeping noukeurig gereël in art. 4-10.

By hierdie reeling het die Heilige Gees die kerke gelei om rekening te hou met die feit dat die kerk in 'n sondige wẽreld bestaan. Die Satan is wel uit die hemel gewerp maar hy erken nie sy nederlaag nie. Sy aanslag op die kerk is daarmee verstewig, sodanig dat Jesus in Openbaring sê: "Wee die bewoners van die aarde en die see, want die duiwel het na julle neergedaal met groot woede, omdat hy weet dat hy min tyd het" (12 : 2b). Hy is veral vertoorn op die kerk - hy haal die volle krag van sy woede uit op die kerk. En hy weet dat die diens van die Woord die hart van die kerk is. Daarom gryp hy alles aan wat die diens van die Woord teenstaan. Hy doen dit listig. Enersyds leer die kerkgeskiedenis ons dat hy die kerk in sy mag kry deur die bedienaars van die Woord ontrou te maak. Daarvan getuig die Pousdom en sektes deur die eeue. Andersyds maak hy ten volle gebruik van die omstandighede in die sondige wêreld wat verhoed dat daar in kerke 'n gereelde bediening kan wees. Daarvan was die kerke van die begin af bewus. Daarom merk ons eerstens die noukeurige bepalings veral in art. 4 om te sorg dat niemand wat die diens van die Woord onwaardig is en deur Satan gebruik kan word, in die kerke indring nie.

Tog hou die kerke in die Ko rekening met die werklikheid van 'n noodtoestand waarin KO art. 4 nie presies toegepas kan word nie. Die Here het beloof dat Hy die wat die Vader Hom gegee het nie sal uitwerp nie, $\mathrm{Hy}$ is met sy kerk al die dae tot aan die voleinding. En waar Hy deur sy Gees en Woord sy kerk vergader, beskerm en onderhou, sal Hy ook in die bediening van die Woord voorsien. Hy kan en voorsien dan ook in normale, maar veral abnormale toestande, bedienaars van die Woord wat nie langs die gewone weg van studie vir die roeping voorberei kan word nie. Veral in die nood van die kerke maak Hy vir die diens voorsiening deur manne met buitengewone gawes.

Hy vestig die aandag op die manne deur die gemeente. Hulle merk op en is oortuig daarvan dat daar ' $n$ man in hulle midde is wat geskik is vir die diens van die Woord. Hulle sien dat Hy die Here liefhet en Hom met oorgawe opreg dien. Hy ken Hom deur sy Woord en het 'n insig in die Woord. Daarom is hy ook nederig, hy stel hom nie aan en dring hom nie op nie. Hy is altyd bereid om te dien. Die gemeente kom ook agter dat hy 'n goeie verstand het en dat hy dit wat in die kerk en die wêreld gebeur kan verstaan in die lig van die Woord van die Here. Alles wat hy weet van die Woord en hoe die Woord die lewe van die kerk en elke gelowige raak, kan hy ook met goeie woorde aan hulle duidelik maak. Hy kan die boodskap wat die Heilige Gees vir die gemeente wil gee so aan hulle bring dat hulle dit kan verstaan, al het hy nie jare geleer om dit te kan doen nie.

Die gelowiges moet so iemand dan onder die aandag van die kerkraad bring en as die kerkraad saamstem dat die man buitengewone gawes 
het, moet hulle hulle oordeel eers aan die Klassis en Partikuliere Sinode voorlê wat dan, as hulle na 'n eksamen, saamstem, die man eers vir 'n rukkie in 'n gemeente (liefs waar 'n predikant is) laat preek en as dit dan duidelik blyk dat hy die gawes het om te kan preek, hom beroepbaar stel. So word in die noodtoestand dan in Art. $8 \mathrm{KO}$ voorsiening gemaak deur 'n wettige roeping tot die diens van die Woord en word iemand nie deur onbehoorlike middele, soos die belydenis (Art. XXXI) dit noem, aan die kerk opgedring nie.

Die kerk het egter nie altyd hierdie weg in noodtoestande gevolg nie. Veral tydens die reformasie, enersyds omdat die kerklike lewe toe nog nie 'n vaste vorm aangeneem het nie, maar ook daarna in 'n baie geringer mate, is op verskillende maniere voorsiening gemaak. Die Franse vlugtelingkerk het so in 1563 bepaal dat 'n kerk wat geen wettige bedienaar van die Woord het nie, moes saam kom en die kerkraad moet een uit hulle midde of uit die gemeente aanstel om gedeeltes uit die Heilige Skrif voor te lees. Die leser mag egter niks daarby tot uitlegging of vermaning sè nie.

Die Skotse kerke het egter reeds in 1560 'n ruimer besluit geneem deur te bepaal dat bekwame lesers wat ook eenvoudige vermaninge kan byvoeg, aangestel kan word. Dit het egter gou gelei tot probleme. Die lesers het hulle as predikante begin gedra en daar is van die ware leer afgedwaal deur hulle onkunde. Die gevolg is dat die vergunning om 'n eenvoudige preek te lewer, ingetrek is deur die Sinode 1581 maar baie jare later is die vergunning weer gemaak.

In Nederland het die kerke gedurende die tyd ook gereel dat voorlesers uit die Skrif moet lees en dan 'n preek van 'n erkende Gereformeerde predikant moes voorlees terwyl hy 'n formuliergebed moes gebruik. Die kerkraad en die Klassis moes toesig hou dat die voorlesers hulle nie voordoen as bedienaars van die Woord nie. Die gebruik om 'n preek te laat voorlees in die afwesigheid van 'n wettig geroepe bedienaar van die Woord, bestaan vandag nog in alle Gereformeerde Kerke. Die leser doen dan net hulpdiens vir die bedienaar van die Woord en hy het geen amp nie.

Hierdie gebruik was gedurende die $18 \mathrm{e}$ en $19 \mathrm{e}$ eeue vir 'n baie lang periode die enigste manier waarop die Woord aan die gelowiges bedien is aan die Oosgrens van die Kaapkolonie en ook aan die Voortrekkers. In Transvaal het die eerste predikant, ds. Van der Hoff, eers vanaf 1853 die nood effens verlig in die Hervormde Kerk. Na die inrigting van die Gereformeerde Kerk te Rustenburg in 1859 moes baie kerke ook maar. veral tot diep in die 20e eeu, deur leesdienste aan die gang gehou word.

Dit was ook ' $n$ tyd waarin daar, veral gedurende oor die 60 jaar (18591920), maar weinig bekwame lesers (weens ongeletterdheid) gevind kon word wat in verskillende kerke kon voorgaan. Tog is daarmee volhard in die sin dat elke ouderling minstens vir een leesdiens elke 3 maande in sy wyk moes sorg en verder moes elke huisgesin, of 'n paar buurhuisgesinne, elke Sondag self godsdiens hou, waarby die huisvader minstens uit die Bybel voorgelees het. Meestal is ook uit preekbundels van Gereformeerde predikante, wat verkrygbaar was, by die huisgodsdiens voorgelees. Hierdie voorsiening, in dié vorm, van die diens van die Woord het deur die eeue, ook in SA die uitnemendste geblyk te wees. 
Tog moet ook op 'n ander gebruik om enigsins, in noodtoestande, vir die diens van die Woord voorsiening te maak, die aandag gevestig word. Dit het ontstaan uit die gewoonte van enkele gelowiges om gedurende die reformasietyd byeen te kom om hulle kennis van die Skrif en die leer te vermeerder.

Die man wat in die samekomste of geselskappe voorgegaan het in die oefeninge is oefenaars genoem. Later is die sieketroosters op die skepe van die HOIK bygevoeg. Gedurende die $17 \mathrm{e}$ eeu het die oefeninge egter 'n gevaar begin inhou vir die suiwerheid van die leer. Daarom het die kerklike vergaderinge reeds vroeg bepalinge gemaak om die oefenaars en sieketroosters te beperk. Gedurende die $19 \mathrm{e}$ eeu, toe die bedienaars van die Woord ontrou geword het, het regsinnige oefenaars meer en meer oefeninge gehou wat die plek van die gewone erediens ingeneem het. Die oefenaars het dan na Skriflesing self die Woord uitgelê en toegepas vir die wat byeengekom het.

Toe die breuk met die Hervormde Kerk in Nederland in 1834 gekom het, was daar nie genoeg predikante wat met die afskeiding meegegaan het om die Woord in alle kerke van die Afskeiding te bedien nie. Oefenaars wat kon preek, is toe in vakante kerke aangestel, maar hulle sou nie die sakramente kon bedien nie. Die Klassis en Partikuliere Sinodes was vir die besondere bepalings waarin die toelating en werk van die oefenaars gereël is, verantwoordelik.

Toe die kerke met die dolerende kerke van dr. Kuyper in 1892 verenig het, is voortgegaan met die aanstelling van oefenaars onder toesig van die Klassis en Partikuliere Sinode.

Die kerke het die oefenaar egter nooit as ' $n$ werklike ampsdraer erken nie en het daarom net met Klassikale en/of Sinodale bepaling volstaan en nooit die KO verander om vir so 'n amp voorsiening te maak nie. Die Christelike Gereformeerde Kerke het tot vandag toe onder artikel $4 \mathrm{KO}$ 'n hele reeks bepalings vir die optrede van 'n oefenaar - maar ook hulle het dit nog nooit tot 'n amp verhef nie. 'n Oefenaar bly net 'n bekwaam geagte broeder wat met advies van die Klassis toestemming verkry om onder die toesig van die kerkraad as broeder onder die broeders " 'n stigtelike woord te spreek", natuurlik eers na deeglike ondersoek van sy leer en lewe deur die kerkraad sowel as die Klassis. Oefenaars het op dieselfde wyse diens gedoen in die Geref. Kleurlingkerke Venterstad en Philipstown. Die vraag ontstaan waarom so 'n broeder nie onder artikel 8 beroepbaar gestel word as hy bekwaam genoeg is nie. Blykbaar moet hier onder bekwaamheid verstaan word 'n vermoë om 'n eenvoudige stigtelike woord te kan spreek maar nie dié van een met buitengewone gawes nie.

Tans meen ek is die werk wat in sommige van die jong kerke deur manne wat bekend staan as helpers en evangeliste gedoen word, te vergelyk met die van die vroeëre oefenaar. Die vraag is net of daar nog die nodige toesig deur die kerkraad en die meerdere vergaderings is.

Dit is egter opvallend dat sedert die Reformasie die kerke konsekwent geweier het om, ten spyte van uitnemende werk wat sommige van hierdie hulpdienaars gedoen het, enigsins amptelike erkenning daaraan te gee. Ter wille van die suiwerheid van die leer is selfs reelings vir toe- 
lating tot die hulpdiens gemaak, maar nooit was daar sprake van 'n amp nie.

Alleen in die uiterste nood en net vir die duur daarvan, en as daar nie geskikte persone ooreenkomstig art. 8 is nie, is van oefenaars gebruik gemaak vir wat ons wil noem 'n eenvoudige preekdiens. En ook eers na eksaminering deur die kerkraad en Klassis en onder strenge toesig van die kerkraad. Dit is opvallend dat die NG Kerk in die vorige eeu en tot nog so laat as in die vyftiger jare (meen ek) van dié eeu aan mense wat in bekwaamheid met die oefenaars vergelyk kan word, die amp van eerwaarde toegeken het met die oog op die sending. Hy is met ' $n$ mindere opleiding beroepbaar gestel en as dienaar van die Woord gestuur onder die heidene, maar is tog nie ten volle as bedienaar van die Woord deur die sendende kerk erken nie. Later is die amp egter opgehef.

Die geskiedenis toon dat die kerke steeds alleen op grond van Skrif en Belydenis vasgehou en Kerkordelik gereël het dat dit "vir niemand geoorloof (sal) wees om die diens van die Woord en sakramente uit te oefen sonder dat hy wettig daartoe beroep en toegelaat is nie. (Art. 3). Verder is ook ag gegee daarop dat nie enigeen beroepbaar is nie, behalwe die wat bekwaam is om ' $n$ ander te leer en aan sekere vereistes voldoen soos o.a. voorgeskryf in 1 Tim 3.

Ten slotte gee ek kortliks nog aandag aan die evangeliste waarvan sprake is o.a. in Ef $4: 11$. Kan dit dan nie gereël word dat die evangeliste of helpers in die jong kerke in die sin ook beskou word as wettige bedienaars van die Woord nie? Met ander woorde, dat 'n evangelisteamp ingestel word nie?

Calvyn (Institusie IV.111.4) beklemtoon dat dit 'n buitengewone amp is wat die Here opgewek het "in die begin van sy Ryk."

Dit was 'n amp wat die naaste aan die van die apostelamp gestaan het. Die evangeliste, o.a. Lukas, Timoteus en Titus, het selfs die diens van die apostels waargeneem.

Ons moet dus onthou dat die apostels, wat op besondere wyse direk deur die Here geroep en onder die onfeilbare leiding van die Heilige Gees gestaan het, vir hulle helpers aangestel het in die tyd toe die Nuwe Testamentiese kerk ingerig moes word. Dit was net soos die apostelamp, soos dit destyds bestaan het, 'n eenmalige roeping van God. Calvyn sê wel dat God ook later weer apostels of altans in hulle plek evangeliste kan opwek soos dit in die tyd van die Reformasie gebeur het om die kerk van die afwyking, van die Antichris, terug te bring. Hy praat hier seker vergelykenderwys om aan te toon dat die Here in tye van totale verwarring weer soos toe op eie wyse vir die diens van die Woord deur besondere manne sal sorg.

Maar u sal begryp dat Calvyn homself en ander groot figure onder die hervormers, nie gelykstel met die apostels of selfs evangeliste wat die Here by die ontstaan van die Nuwe Testamentiese Kerk gebruik het nie. Die amp van evangelis, sê Calvyn dan, soos in die Skrif vermeld. het in 'n behoorlik ingerigte kerk geen plek nie. 